\title{
Geochronological provinces of the Amazonian Craton
}

1 Geochronological Research Center - Geoscience Institut of University of São Paulo - Brazil, P.O. Box 11348 - CEP 05422-970, São Paulo - SP, Brazil. E-mail: ccgtassi @ usp.br

2 Isotope Geology Laboratory - CG - Federal University of Pará - Brazil, P.O. Box 1611 - CEP 66059 - Belém - PA, Brazil

The Amazonian Craton (AC), located in the north of South America, is surrounded by Neoproterozoic orogenic belts and is divided into six major geochronological provinces: Central Amazonian CAP (> $2.3 \mathrm{Ga}$ ); Maroni-Itacaiúnas - MIP (2.2-1.95 Ga); Ventuari-Tapajós - VTP (1.95-1.80 $\mathrm{Ga})$; Rio Negro-Juruena - RNJP (1.8-1.55 Ga); Rondonian-San Ignácio - RSIP (1.55-1.3 Ga), and Sunsás - SP (1.3-1.0 Ga).

$\mathrm{Sr}, \mathrm{Pb}$ and $\mathrm{Nd}$ isotopic compositions of igneous and orthogneissic rocks from the AC show that a significant addition of new crustal material from the upper mantle occurs during the Paleo- and Mesoproterozoic. The geochronological pattern indicated that the Archean protocraton of AC consisted formerly of independent microcontinents that were amalgamated by Paleoproteorozic orogenic belts, between 2.2 and $1.95 \mathrm{Ga}$. Part of the MIP and RSIP, and the whole of VTP and RNJP evolved by addition of juvenile magmas to the crust from 1.95 to $1.4 \mathrm{Ga}$, while the crustal evolution of SP and part of MIP and RSIP were associated with reworking of the older continental crust. No exposure of the Archean crust is known in RSIP and SP, and the Sm-Nd model ages of granitoids from those provinces indicate that the reworked crust was mostly derived from partial melting of Paleoproterozoic and Mesoproterozoic material, suggesting little or no involvement of the Archean crust in the southwestern portion of the AC.

\section{Introduction}

The isotopic studies and the definition of geochronological provinces are useful for providing a basis for the understanding of crustal evolution processes and their tectonic implications on a continental scale. That is the reason why we have summarized the geochronological pattern of the Amazonian Craton (AC). We have attempted to comment on isotopic and geological data, emphasizing their geographic distribution in agreement with the geochronological provinces established in previous work (Cordani et al. 1979; Teixeira et al. 1989; Tassinari et al. 1996; and Tassinari 1996). Those geochronological provinces are shown in Figure 1. Few changes are noticed in relation to the author's models, an exception was made with the recently proposed Ventuari-Tapajós

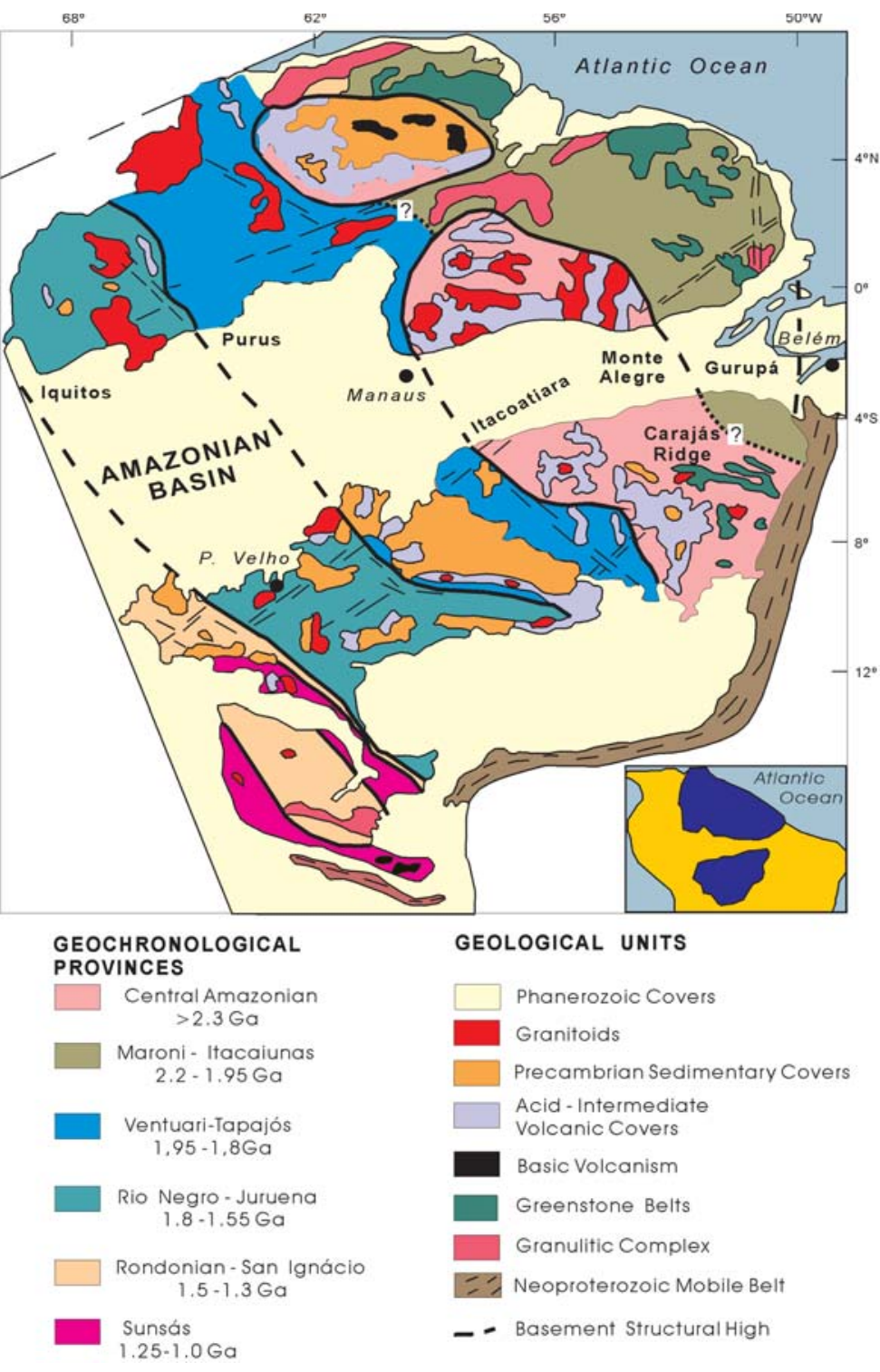

FIigure 1 Sketch map showing the distribution of the Geochronological Provinces and the main lithological associations of the Amazonian Craton, north of South America. (map based on Tassinari, 1996)

Province (Tassinari, 1996) and the new radiometric ages, which were useful for redefining the boundaries between provinces.

The geochronological provinces are defined, partially following the principles of Stockweel (1968) for the structural and geochronological provinces of the Canadian Shield, as major zones within cratonic areas, where a characteristic geochronological pattern predominate, and the age determinations obtained by different isotopic 
methodologies for different geological units are very coherent. The divisions are made mainly on the basis of the ages of the metamorphic basement and geological characteristics. In general, a broad time interval for the provinces was established due to the fact that the geology of most of the AC is poorly known. Therefore, the provinces mainly differ from each other in the ages of metamorphic terranes and their geological history.

Each province may contain anorogenic igneous rocks and sedimentary covers of widely different younger ages, in agreement with the orogenic history of the neighboring areas. Furthermore, geochronological provinces may include some older preserved nuclei, when their tectonic evolution has an ensialic character or some younger metamorphic rocks were produced by later reworking processes.

The geographical boundaries between geochronological provinces in the AC have been reasonably welldefined mainly by geochronological data with some geological and geophysical support, although some limits are still not well characterized due to the overprint of age determinations and/or lack of reliable geological information. Therefore some boundaries are still open to question. The precise location of the geochronological boundaries in the field must be established by further detailed geological work.

The geochronological provinces may include one or more orogenic episodes, within their respective timeperiods. Orogeny is here considered, according to Stockweel (1968), as a period of metamorphic episodes accompanied by deformation, partial melting and syntectonic granitic intrusions, and not as the broader concept of a complete orogenic cycle, involving subsidence, deposition of sediments, metamorphism, syn- and post-tectonic magmatic activities and anorogenic episodes.

\section{Geochronological provinces}

The AC is one of the largest cratonic areas in the world, and occurs in the northern part of South America. It covers an area of about $4.3 \times 10^{5} \mathrm{~km}^{2}$ and is divided into two Precambrian shields, the Guaporé and Guiana Shields, separated by the Paleozoic Amazonian Sedimentary Basin (Figure 1). The craton is surrounded by Neoproterozoic orogenic belts (Tucavaca in Bolivia, Araguaia-Cuiabá in central Brazil and Tocantins in northern Brazil), and has been relatively stable since $1.0 \mathrm{Ga}$ ago.

The craton can be subdivided into six major geochronological provinces, based on the age determinations, structural trends, proportions of lithologies and geophysical evidences (Teixeira et al., 1989, Tassinari, 1996). The majority of the radiometric ages, which comprise about 3,000 age determinations, were mainly obtained by $\mathrm{Rb}-\mathrm{Sr}$, K-Ar, Sm-Nd (model ages) and zircon U-Pb methods, although whole-rock $\mathrm{Pb}-\mathrm{Pb}$ ages are also available.

The recognized Geochronological Provinces of the AC comprise a stable Archean nuclei, which is included in the Central Amazonian Province, and Paleoproteorozic and Mesoproterozoic Provinces such as Maroni-Itacaiúnas (2.2 to $1.95 \mathrm{Ga})$; VentuariTapajós (1.95-1.8 Ga); Rio Negro-Juruena (1.8-1.55 Ga); Rondonian-San Ignácio (1.55-1.30 Ga) and Sunsás (1.30-1.0 Ga) (Figure 1).

\section{Central Amazonian Province (CAP)}

The CAP is composed by the oldest continental crust of the Amazonian craton which was not affected by the $2.2-1.9$ Ga TransAmazonian Orogeny. However, during the Paleoproteorozic, it was the scene of expressive magmatic and sedimentary events. The basement of the CAP probably comprises a number of contrasting geological units in relation to their lithology, age and geological identi-
Table 1 Age Determinations of Central Amazonian Province.

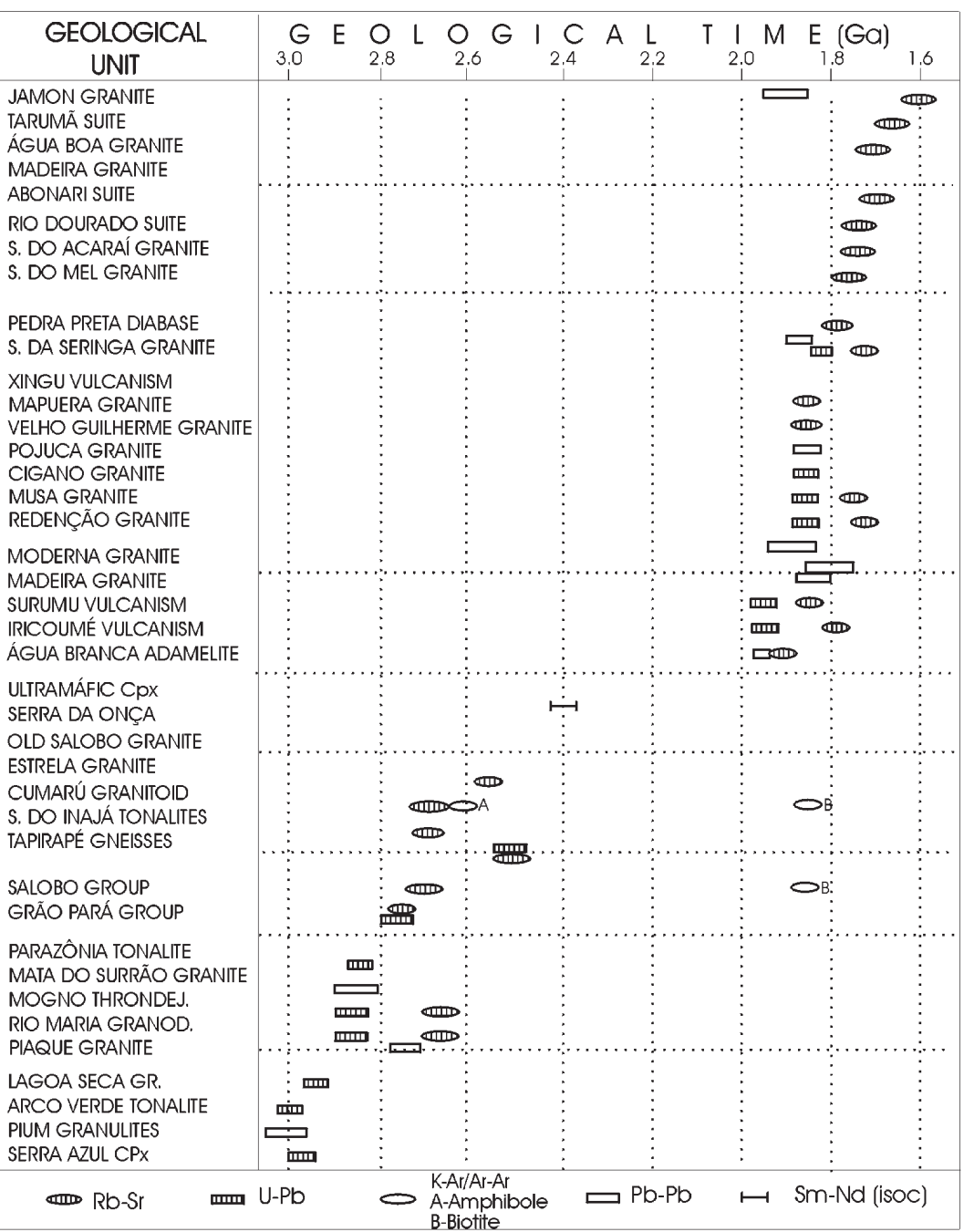

fication. In the southeastern CAP, the Archean Carajás Metallogenic Province represents the better-studied region of the AC. On the other hand, the western adjacent region and its continuity to the north of the Amazonas syneclise, are not well exposed, poorly known, and very few geochronological results are available. Taking into account these dissimilarities for the purpose of description and discussion of the geochronology, the CAP will be divided into two domains, separated by Maroni-Itacaiúnas Province: the first one, named CarajásIricoumé Block, subdivided into the Carajás and the Xingú-Iricoume areas, and the second one composed of the Roraima Block. The geochronological pattern of the CAP is showed in Table 1 .

\section{Carajás-Iricoumé Block: the Carajás Area.}

The Carajás area, the most important mineral province of Brazil (iron, copper, gold, manganese, nickel, etc.), is the best preserved Archean region of the AC. It was formed and tectonically stabilized during the Archean and it is divided into three E-W domains (DOCEGEO 1988; Costa et al. 1995): the Rio Maria granite-greenstone terranes and the surrounding northern Itacaiúnas and southern Pau D'Arco shear belts. The Rio Maria terranes are interpreted as a preserved nucleus, while at least part of both shear belts are the result of the nucleus deformation. The Itacaiúnas shear belt includes high-grade rocks (Pium Complex), gneisses (Xingu Complex), volcano-sedimentary sequences such as the Grão Pará Group, and granitoids (Plaquê Suite, Estrela Granite, etc.). The Pau D'Arco shear belt consists of greenstone sequences (Andorinhas Supergroup) as well as TTG associations.

Further, the Carajás area was only affected by the widespread Paleoproterozoic granitic intrusions and by local sedimentary depo- 
sition. The oldest stratigraphic units dated so far are the Andorinhas greenstone and the Arco Verde Tonalite (2.90-2.98 Ga; Pimentel and Machado, 1994, Macambira and Lancelot, 1996). However, zircons aged up to 3.7 Ga have been reported in Paleoproterozoic granites and in sedimentary sequences (Machado et al. 1991; Macambira et al.1998). The evolution of the Rio Maria granite-greenstone terranes finished with the closure of the marginal greenstone basins and the intrusion of the $2.87 \mathrm{Ga}$ syn-tectonic granitoids, such as the Rio Maria Granodiorite. The geochronological data establish a short episode $(<150 \mathrm{Ma})$ of continental crust formation in this area (Macambira and Lancelot 1996). The $\mathrm{Nd}$ and $\mathrm{Sr}$ isotopic results agree with this hypothesis and suggest a $>3.04 \mathrm{Ga}$ crust, as the source of the Archean granitoids (Sato and Tassinari, 1997, Dall'Agnol et al., 1999). The 2.85 Ga Xingú gneissic Complex (Machado et al., 1991) is the regional basement and has the oldest rocks in the Itacaiúnas shear belt. The $\mathrm{Sr}$ and $\mathrm{Nd}$ isotope data yield an age of ca. 3.0 Ga for the source of these gneisses (Sato and Tassinari, 1997) contemporaneous with the protolith of the Pium granulite (3.0 Ga; Pidgeon et al., 1998). The formation of the granulites ( $2.86 \mathrm{Ga}$; Pidgeon et al., 1998) is also coeval with the gneisses, suggesting that both types of rock were generated by the same regional event.

The main neoarchean geological events of the Carajás area took place in the Itacaiúnas belt, generating the Carajás basin, while the Rio Maria terrane was quite tectonically stabilized. In the transtensive phase, openings were filled by volcanosedimentary sequences, such as the Grão Pará Group at 2.76 Ga ago (Wirth et al., 1986). Mafic-ultramafic complexes, such as the Luanga complex and the Plaquê granites, yielded ages around 2.7 Ga (Araujo et al., 1988). Furthermore, Machado et al. (1991) proposed another tectono-metamorphic event affecting the Itacaiúnas shear belt between 2.50 and 2,58 Ga, with associated A-type intrusions, such as the Estrela Granite. The Paleoproterozoic is characterized by the emplacement of $1.88 \mathrm{Ga}$ granites (e.g. Wirth et al. 1986, Machado et al., 1991). This plutonism is associated with an extensive thermal event (e.g. Costa et al., 1995), responsible for the warming of the region, inducing the reported $\mathrm{Rb}-\mathrm{Sr}$ and $\mathrm{K}-\mathrm{Ar}$ "Transamazonian" ages on metamorphic rocks (Macambira and Lafon, 1995). The $\mathrm{Sr}$ and $\mathrm{Nd}$ isotope system (Macambira et al., 1990, Dall'Agnol et al., 1999) suggests an origin from the anatexis of $2.87 \mathrm{Ga}$ lower crust, probably caused by underplating or intrusion of mantle-derived mafic magmas (Dall'Agnol et al., 1994).

\section{Carajás-Iricoumé Block: The Xingú-Iricoumé Area.}

The Xingú-Iricoumé area is composed of unmetamorphosed Paleoproterozoic plutonic and volcanic rocks covered by sedimentary sequences, which rest unconformably on an undated basement complex, and are crosscut by several granitic plutons. The Archean age for the metamorphic basement is proposed based on some Archean $\mathrm{Nd}$ model ages (TDM) and the presence of granitoids of ca. $1.96 \mathrm{Ga}$ old, intrusive in the northern CAP and in the surrounding TransAmazonian Central Guiana Belt. The Uatumã Supergroup is composed of volcanic and younger plutonic rocks. In the northern part, the volcanic and plutonic rocks are called the Iricoumé and Mapuera groups, while those of the southern sector are named the Iriri Group and Maloquinha/Rio Dourado intrusive Suites, respectively. The oldest granitoids are the calc-alkaline Água Branca Monzogranite (1.96 and $1.94 \mathrm{Ma}$; e.g. Almeida et al., 1997), in the northernmost area, and the "Parauari" Granite (1.92 Ma; Macambira et al., 1992), which occur close to the Xingu river. Zircons from the northern Iricoumé volcanic rocks yielded an age of $1.96 \mathrm{Ga}$ (Schobbenhaus et al., 1994). Subalkaline to alkaline granites showing similarities with the A-type and rapakivi granites, widespread in the area, are interpreted as anorogenic (e.g. Dall'Agnol et al., 1987, 1994). In the northernmost area, some of these granitic plutons are highly tinmineralized and intrusive in the Iricoumé Group, as the $1.83 \mathrm{Ga}$ Madeira (Fuck et al., 1993) and Água Boa granites (both in the Pitinga tin-mine), and also the 1.81 Ga Moderna Granite (Santos et al., 1997). In the southern area, the felsic volcanic rocks of the Xingú
River yielded a Rb-Sr age of $1.86 \mathrm{Ga}$ (Cunha et al., 1981). The Nd model ages (TDM) indicate values between 2.5 and $2.6 \mathrm{Ga}$ for the source of the felsic volcano-plutonism from the Iriri-Xingú region (Sato and Tassinari, 1997).

\section{The Roraima Block}

The Roraima block occurs in the northern part of AC and is separated from the Iricoumé-Carajás block by the 2.2-1.95 Ga MaroniItacaiúnas Province. It is completely covered by the $2.0-1.95 \mathrm{Ga}$ Surumu acid volcanic rocks (Schobbenhaus et al., 1994), and by the sedimentary sequences of the Roraima Group, which overlies the Surumu volcanism. Interbedded with the Roraima sediments, sills of mafic rocks and horizons of pyroclastic volcanic rocks dated at 1.65 Ga (Priem, 1973) are observed. Furthermore, the Roraima Group is intersected by several 1.88-1.6 Ga mafic dykes (Hebeda et al., 1973 and Teixeira, 1978).

An age older than $2.3 \mathrm{Ga}$ for the Roraima block metamorphic basement is assumed based on the fact that the Roraima block is covered by ancient unmetamorphosed volcanic rocks (1.95 Ga), which has the same age as the neighboring high-grade metamorphic terranes of the Maroni-Itacaiúnas Province. Thus it is possible to assume that the Roraima block acted as a stable foreland for the marginal Paleoproterozoic belt.

\section{Maroni-Itacaiúnas Province - MIP}

The CAP is surrounded to the north and northeast by the $2.2-1.95 \mathrm{Ga}$ MIP, which is characterized by a large exposure of metavolcanic and metasedimentary units, deformed and metamorphosed at greenschist to amphibolite facies, as well as by granulitic and gneissicmigmatitic terranes. The southern boundary of CAP and MIP, at the northern part of the Serra dos Carajás area, is still uncertain, due to the lack of reliable geological and geochronological information about that area.

The MIP geochronological pattern is very complete and concordant along the whole province, suggesting that its evolution took

Table 2 Age Determinations of Maroni-Itacaiúnas Province.

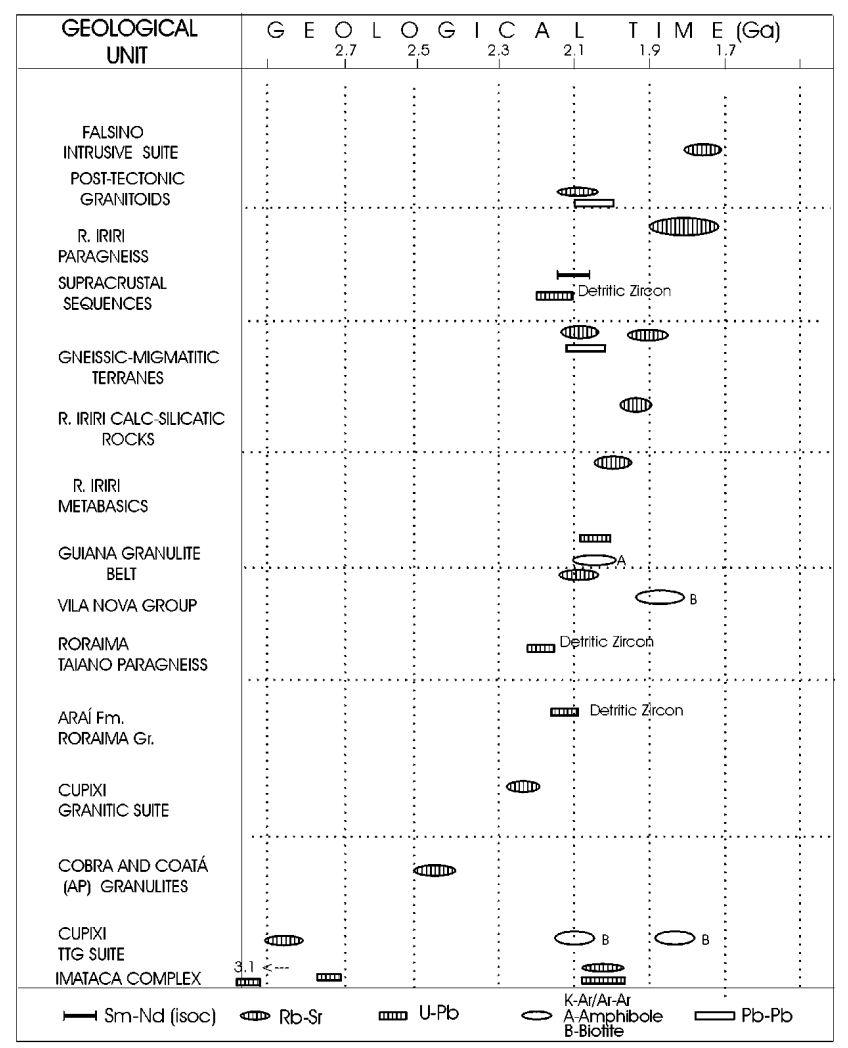


place during a major event in the Paleoproterozoic between 2.2 and $1.95 \mathrm{Ga}$ (Table 2). In turn, remnants of some older Archean basement within MIP have been identified. They generally consist of high-grade polymetamorphic rocks, such as the allocthonous $(>3.0$ Ga) Imataca Complex, in Venezuela (Montgomery and Hurley, 1978), and the exotic (2.9-2.6 Ga) Cupixi terranes in Amapá, Brazil (Lima et al. 1986), which present a strong Paleoproteorozic metamorphic overprint. These ancient nuclei, together with $2.0-1.9 \mathrm{Ga}$ $\mathrm{Rb}-\mathrm{Sr}$ age determinations with high $\mathrm{Sr}$ initial ratios of 0.710 obtained from metamorphic rocks from the south MIP (Santos et al., 1988), suggest a partial ensialic character for the tectonic evolution of Maroni-Itacaiúnas Province.

The available isotopic data for the high-grade metamorphic rocks, regarded as the Central Guyana Granulitic Belt, including the Falawatra and Kanuku Groups, indicate zircon U-Pb ages and $\mathrm{Rb}-\mathrm{Sr}$ isochronic ages between 2.1 to $1.9 \mathrm{Ga}$ (Priem, 1973, Priem et al., 1978), and Sm-Nd mantle-depleted model ages ranging from 2.2 to $2.0 \mathrm{Ga}$ (Ben Othman et al., 1984). The geochronological results clearly indicate that the granulitic terranes were separated from the upper mantle during the Paleoproterozoic period.

The $\mathrm{Rb}-\mathrm{Sr}, \mathrm{Pb}-\mathrm{Pb}, \mathrm{Sm}-\mathrm{Nd}$ and $\mathrm{U}-\mathrm{Pb}$ age determinations obtained for syntectonic granitoids and gneissic-migmatitic terranes of "Série Ille de Cayenne" indicate ages in close agreement to 2.1-1.95 Ga, with coherent $\mathrm{Sr}$ initial ratios around 0.7018-0.7024, $\mu_{1}$ value of 8.2 and positive $\varepsilon_{\mathrm{Nd}}$ values. These parameters suggest that the rocks were added to the crust during the Paleoproteorozic (Teixeira et al., 1985 and Milési et al., 1995).

The MIP comprises a large proportion of metavolcano-sedimentary sequences metamorphosed on greenschist to amphibolite facies (Paramacá-Bonidoro; Barama-Mazaruni; Carichapo-Pastora and Vila Nova Units), which are associated with Paleoproteorozic granite-greenstone terranes (Gibbs, 1980). Detritic zircon U-Pb ages from metagraywacks and conglomerates yielded ages between 2.2 and 2.1 Ga (Gibbs, 1980 and Milési et al., 1995). The older ages were interpreted as the basement rock-forming ages. The associated bimodal volcanism gave Sm-Nd whole-rock isochron of $2.1 \mathrm{Ga}$ (Gruau et al. 1985), which is in close agreement with the detritic zircon U-Pb ages around 2.1 Ga (Egal et al., 1994). The supracrustal sequences are intruded by different types of granites, with ages around 2.08 Ga (Milési et al., 1995).

\section{Ventuari-Tapajós Province - VTP}

The Central Amazonian Province is bounded in the west by the VTP, which occurs in a prominent NW-SE trend and can be followed from the Ventuari River in southern Venezuela to the Tapajós River in Brazil (Figure 1). The VTP, as a whole exhibits a geochronological pattern slightly younger than the Maroni Itacaiúnas Province, with ages ranging from $1.95 \mathrm{Ga}$ to $1.8 \mathrm{Ga}$ (Table 3). The lithologies of VTP, although not thoroughly documented, differ substantially from that of MIP. The VTP comprises mainly calc-alkaline granitoids, while the MIP, in contrast, includes large amounts of metavolcanosedimentary sequences and granulitic rocks.

The northern part of VTP is composed of granite-gneissic rocks with granodioritic to quartz-dioritic compositions, gabbros and amphibolites, which are displayed within the Ventuari Petrotectonic Domain (Barrios, 1983). U-Pb zircon ages between 1.85 and $1.83 \mathrm{Ga}$ are available for the Macabana and Minicia Gneisses and Atabapo quartz-diorite, which are in close agreement with the $\mathrm{Rb}-\mathrm{Sr}$ age determinations of $1.83 \mathrm{Ga}$ and $\mathrm{Sr}$ initial ratios of around 0.7027 (Gaudette and Olszewski, 1981; Tassinari et al., 1996).

The southern part of VTP presents the same lithologic assemblage described above, predominantly with calc-alkaline granodioritic rocks and gneisses with tonalitic composition, metamorphosed in the amphibolite facies. The zircon U-Pb determinations and whole-rock Rb-Sr ages varying from 2.0 to $1.85 \mathrm{Ga}$ (Vignol, 1987, Gaudette et al. 1996, Tassinari 1996 and Iwanuch, 1999). The Sm$\mathrm{Nd}$ mantle-depleted model ages between 2.1 to $2.0 \mathrm{Ga}$, indicate the main period of continental accretion in the VTP. $\varepsilon_{\mathrm{Nd}}$ values, calculated for $2.0 \mathrm{Ga}$, range from +2.1 to -1.6 (Sato and Tassinari, 1997),
Table 3 Age Determinations of Ventuari-Tapajós Province.

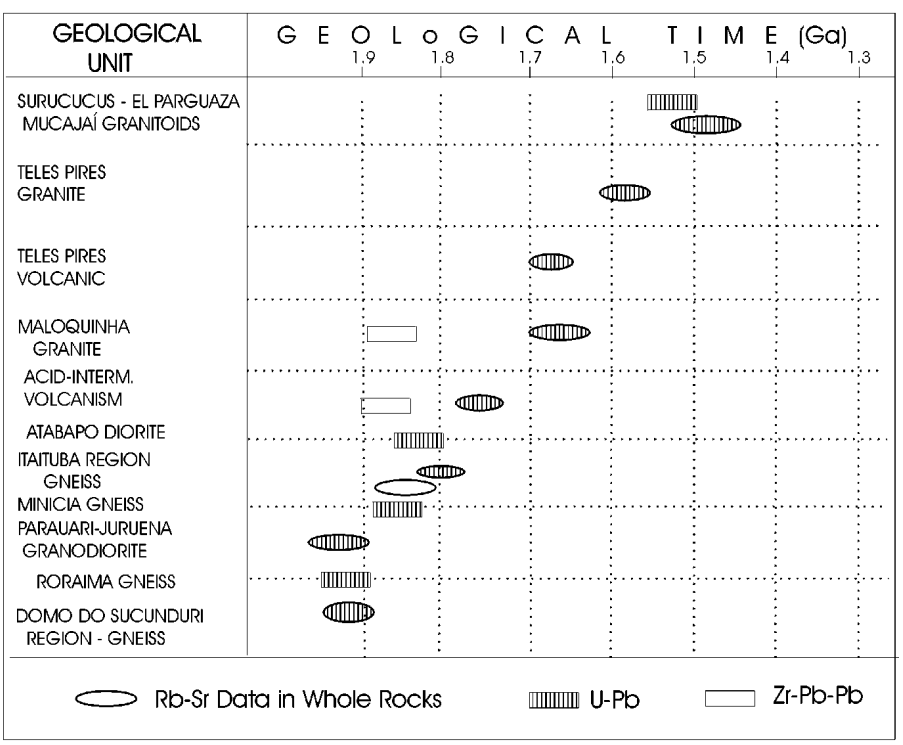

which suggest a mixing of some subordinated crustal component with predominant mantle-derived magmas. This mixture in the external zones of VTP was developed on or adjacent to Archean CAP.

Scattered occurrences of greenschist facies metavolcano-sedimentary sequences, included in the supracrustal Jacareacanga Suite (Santos et al. 1997), are observed in the southern part of VTP. They are composed of schists, phyllites, metachert, banded iron formations and talc-schists. The unit has been dated, through $\mathrm{U}-\mathrm{Pb}$ detritic zircon age and $\mathrm{U}-\mathrm{Pb}$ zircon age of Parauari intrusive granitoid, at 2.1 to $1.92 \mathrm{Ga}$ (Santos et al., 1997).

The southern part of VTP was affected by calc-alkaline Iriri acid to intermediate volcanism and associated Maloquinha Granitoids with ages between 1.89-1.84 Ga (Santos et al., 1997; Vasquez et al., 1999 and Moura et al., 1999), and by the acid-intermediate Teles Pires volcano-plutonism dated at 1.7-1.6 Ga (Basei, 1977 and Tassinari, 1996). A sedimentary platform covers the Gorotire and Beneficente Groups, dated at 1.8-1.6 Ga and 1.7-1.3 Ga respectively (Santos et al., 1997 and Tassinari et al. 1978), overlying these undeformed volcanic rocks and intersected by mafic dikes.

The $1.55 \mathrm{Ga}$ El Parguaza and Surucucus anorogenic rapakivi granites (Gaudette et al., 1978; Tassinari, 1996 and Santos et al., 1999) occurs in the northern part of VTP and represent intra-plate magmatism. In the same way, the $1.55 \mathrm{Ga}$ Rapakivi granites of the MucajaI Suite and the associated Repartimento anorthosites and Serra da Prata charnockites form part of a charnockitic-anorthositicRapakivi association related to the Parguaza event (Fraga and Reis, 1995; Fraga et al., 1997 and Santos et al., 1999).

\section{Rio Negro-Juruena Province (RNJP)}

The RNJP is located on the western side of VTP, and its exposures straddle along a NW-SE trend approximately $2000 \mathrm{~km}$ long and 600 $\mathrm{km}$ wide (Figure 1) in the western portion of the Amazonian Craton, involving parts of Brazil, Venezuela and Colombia.

The basement rocks of this province are composed almost entirely of 1.8-1.55 Ga granite-gneisses and granitoids with mainly granodioritic and tonalic compositions. In the northern part occur predominantly biotite-titanite monzogranites (Dall'Agnol and Macambira, 1992), while in the southern part the basement rocks are composed of granite-migmatite terranes and gneisses with tonalitic compositions. In general, the rocks are metamorphosed on amphibolite facies, although some granulites are also present. The geochronological pattern available for RNJP basement (Table 4) involves $\mathrm{Rb}-\mathrm{Sr}, \mathrm{Pb}-\mathrm{Pb}$ and $\mathrm{U}-\mathrm{Pb}$ ages within 1.8 and $1.7 \mathrm{Ga}$ and $1.65-1.55 \mathrm{Ga}$ time periods. The initial ${ }^{87} \mathrm{Sr} /{ }^{86} \mathrm{Sr}$ ratios between 
Table 4 Age Determinations of Rio Negro-Juruena Province.

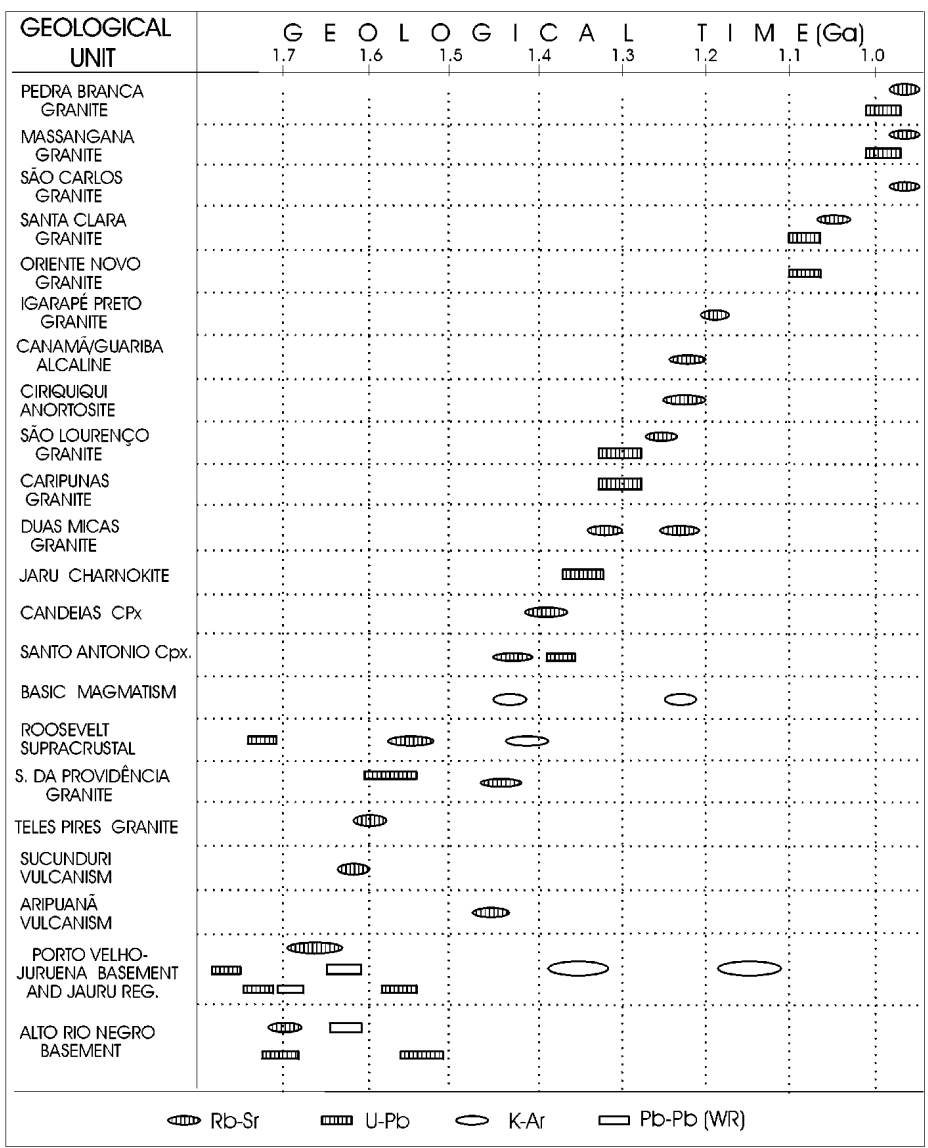

0.702 and 0.706 , the $\mu_{1}$ values around 8.0 and the majority positive $\varepsilon_{\mathrm{Nd}}$ values relative to CHUR ( +4 to -2 ), calculated for $1.8 \mathrm{Ga}$, suggest an juvenile origin for most of the Rio Negro-Juruena basement rocks (Tassinari et al. 1996). According to Payolla et al. (1998), in some regions of the southern part of RNJP, gneissic rocks occur within the metamorphic basement, with zircon $\mathrm{U}-\mathrm{Pb}$ ages of 1.73 and $1.57-1.53 \mathrm{Ga}$, which are normal for the province, as well as an age of $1.42 \mathrm{Ga}$, which suggests a younger metamorphic overprint in the area.

The Jauru region, located in the southwestern portion of the RNJP, includes some metavolcano-sedimentary sequences interpreted by some authors, like Monteiro et al. (1986), as greenstone belts sequences. It was considered in previous works (Teixeira et al., 1989 and Tassinari et al., 1996) as an ancient nucleus preserved within younger RSIP. After the $1.8-1.55 \mathrm{Ga}$ zircon U-Pb ages and 1.9-1.75 Ga Sm-Nd mantle depleted model ages obtained by Geraldes et al. (1999) on granitic and orthogneissic rocks, which are in agreement with the RNJP geochronological pattern, the Jauru area was considered by the last authors as a possible extension of the RNJP.

Supracrustal sequences are scattered within the RNJP. They are represented in the southern part by the Roosevelt metavolcano-sedimentary unit, which is composed of dacites, ryolites, andesites, tuffs, volcanic breccias, claystones, sandstones and banded iron formations, metamorphosed on greenschist facies. Zircons from dacites yielded U-Pb age of $1.74 \mathrm{Ga}$ (Santos et al., 1999), while a wholerock $\mathrm{Rb}-\mathrm{Sr}$ isochron for the volcanic rocks gave an age of $1.56 \mathrm{Ga}$ (Tassinari, 1996). The older age is interpreted as the time of volcanism, and the younger age could be related to the metamorphism. Small remnants of quartzites of the Tunuí Group occur at scattered localities in the northern part of RNJP.

In the southern part of the RNJP the Caiabis Group, composed of volcano-sedimentary sequences characterized by a calc-alkaline acid-intermediate undeformed volcanism and sedimentary rocks typical of shallow water environments, rest on the metamorphic basement. Furthermore, alkaline, tholeiitic and calc-alkaline basalts with ages of 1.4 and $1.2 \mathrm{Ga}$ (Tassinari et al., 1978) are present in the sedimentary sequences. In general, these volcano-sedimentary units are related to rift systems produced within stable continental regions, as a reflex of orogenic activities in neighboring areas.

The anorogenic granitoid magmatism within the RNJP is represented by A-type and within-plate granites, mainly with syenogranitic and monzogranitic composition, some of them with Rapakivi textures, associated with gabbro, syenite, mangerite and charnockites. The age determinations for anorogenic granitoids are summarized in Tassinari et al. (1996) and Bettencourt et al. (1999). These findings showed that the plutonism were emplaced episodically between $1.6 \mathrm{Ga}$ and $0.97 \mathrm{Ga}$. In this way the Serra da Providencia Intrusive Suite is the oldest, with ages between 1.6-1.53 Ga, followed by the Santo Antonio Massif and Teotonio Intrusive Suite with ages around $1.4 \mathrm{Ga}$, by the younger Rapakivi Granites of Rondonia with ages ranging from 1.3 to $1.2 \mathrm{Ga}$, and finally by the youngest anorogenic granites with ages between 1.1 to $0.95 \mathrm{Ga}$. Mafic magmatic activities in the RNJP occur within three different time-periods; the older between 1.4 and $1.35 \mathrm{Ga}$ and the others ranging from 1.25 to $1.15 \mathrm{Ga}$ and from 0.98 to 0.95 Ga (Tassinari, 1996).

\section{Rondonian-San Ignácio Province (RSIP)}

The RSIP (southwestern portion of the AC) is bounded to the east by the RNJP and to the south and southwest by Sunsás Province (SP). The 1.55 to $1.30 \mathrm{Ga}$ metamorphic basement is composed of granite-gneiss-migmatitic terranes and granulitic rocks. In general, these rocks are metamorphosed in amphibolite or granulite facies conditions. Some Paleoproteorozic granulitic inlets, like the Lomas Manéches Group in Bolivia (Litherland et al., 1979) are dispersed within the province. The RSIP shows strong overprint NE-SW

Table 5 Age Determinations of Rondonian-San Ignácio Province.

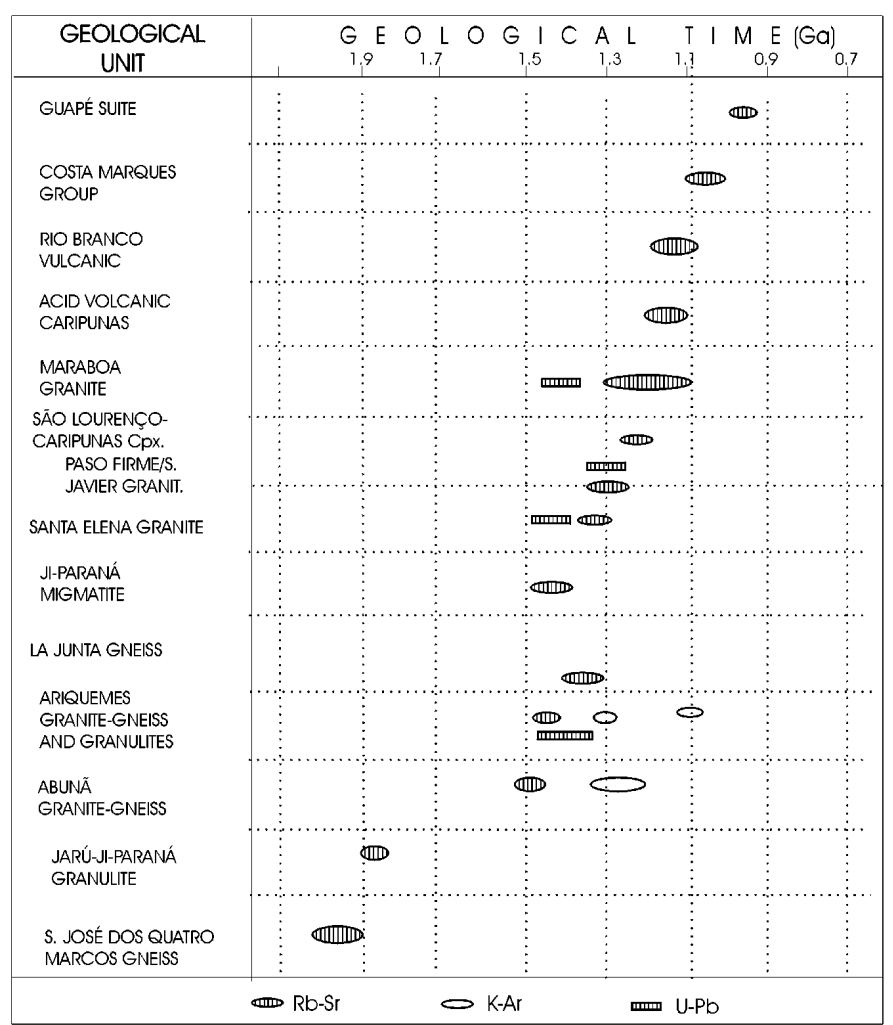


structures and has some regions with clear ensialic characters and others with juvenile magmatic characteristics.

The geochronological pattern for the RSIP basement rocks, summarized in Table 5, includes a group of $\mathrm{Rb}-\mathrm{Sr}$ age determinations between 1.5 and $1.37 \mathrm{Ga}$, with ${ }^{87} \mathrm{Sr} /{ }^{86} \mathrm{Sr}$ initial ratios ranging from 0.703 to 0.710 (Teixeira and Tassinari, 1984) and zircon U-Pb ages varying from 1.49 to $1.33 \mathrm{Ga}$ (Geraldes et al., 1999). The granitoids of the RSIP yielded two groups of Sm-Nd depleted-mantle model ages. The first one, obtained from samples of the Pontes de Lacerda region, around $1.5 \mathrm{Ga}$, was considered by Geraldes op. cit. as related to Santa Helena Volcano-Plutonic Arc. The older group, composed of samples from the entire RSIP with ages from 2.0 to 1.7 $\mathrm{Ga}$ which coincide with the estimated mantle-extraction period of the RNJP (Geraldes et al., 1999 and Sato and Tassinari, 1997), indicates the development of crustal reworking processes within the province.

Metavolcano-sedimentary sequences, represented by the Ascencion Group in Bolivia, indicate an metamorphic age of 1.34 $\mathrm{Ga}$ (Litherland et al., 1986). The K-Ar cooling ages between 1.35 and $1.30 \mathrm{Ga}$ suggest the beginning of tectonic quiescense period of the RSIP. Post-orogenic and anorogenic magmatic activities are represented by the São Lourenço-Caripunas Intrusive Suite $(1.31 \mathrm{Ga})$, the Santa Clara Suite (1.08 Ga), Costa Marques Group (1.02 Ga) and the younger granites of Rondonia $(0.99 \mathrm{Ga})$ (Bettencourt et al., 1999). The occurrence of the $1.1 \mathrm{Ga}$ undeformed acid volcanism is very scattered within the province. Sedimentary rocks associated with alkaline basalts were deposited around 1.1-1.0 Ga in NW-SE continental rift system, which correspond to the age of the basalts that intruded into the lower sedimentary sequences of the Guajará Mirim Group.

\section{Sunsás Province (SP)}

Sunsás Province is the youngest tectonic unit of the AC. It is best exposed in the southwestern portion of the craton, where it consists of a zone with rocks generated by the erosion of the older continental crust, the deposition and subsequent deformation and metamorphism of these sediments and an older basement between 1.3 to 1.0 $\mathrm{Ga}$ (Litherland et al., 1986). This metamorphic episode is contemporaneous with syntectonic magmatic activities. The 1.18 Ga Garzon Granulitic belt, which occurs in the Colombian Andes as a basement tectonic window, could be a possible extension of the Sunsás Belt towards the north.

\section{Table 6 Age Determinations of Sunsás Province.}

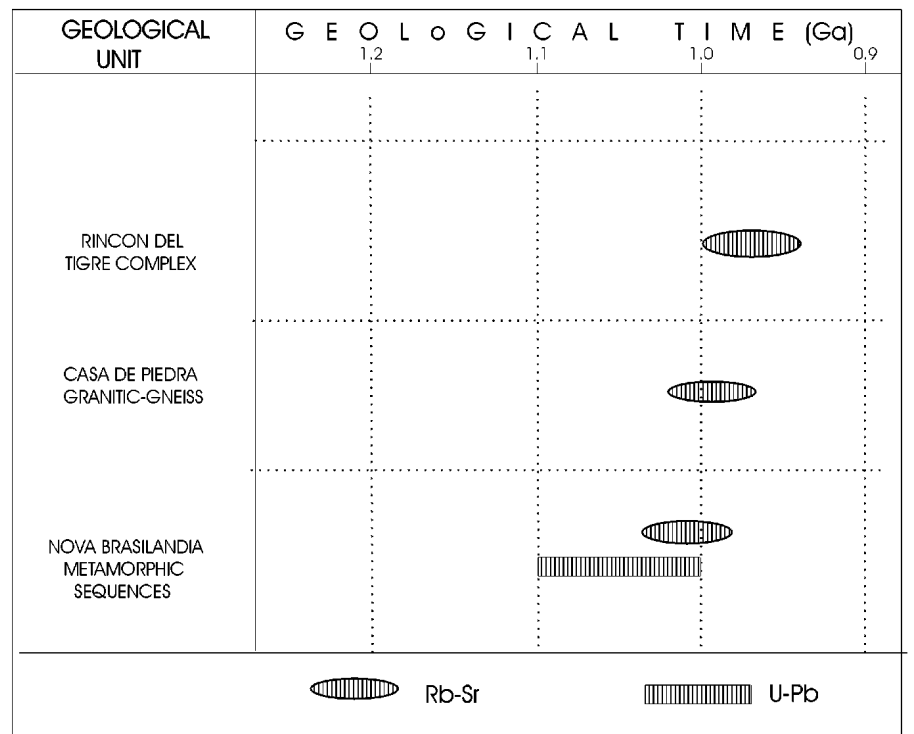

The Sunsás belt is represented by the metasedimentary Aguapei and Sunsás Groups, the Pontes e Lacerda metavolcano-sedimentary unit, and the Nova Brasilandia metavolcano-plutonic-sedimentary sequence. The geochronological data of the Nova Brasilandia Sequence gave a U-Pb zircon age around $1.1 \mathrm{Ga}$ for syntectonic plutonic activities, and of $0.99 \mathrm{Ga}$ for the post-tectonic magmatism (Rizzotto et al., 1999). These authors, based on SHRIMP U-Pb results, suggest an age of $1.21 \mathrm{Ga}$ as the maximum time for the deposition of Nova Brasilandia metassediments. The Sunsás and Pontes de Lacerda units have an estimated age between 1.3 and $1.1 \mathrm{Ga}$ (Litherland et al., 1986; Geraldes, 1996). The Casa de Piedra Granitoid and the Rincon del Tigre mafic complex, dated around 1.0 Ga (Litherland et al., 1986) complete the post-tectonic activities within the SP.

\section{Final considerations}

Although the geochronological data base of the AC is far from complete, the present geochronological pattern enables us to point up some aspects which should be considered for crustal evolution models for the Amazonian region during the Precambrian period.

- $\mathrm{Sr}, \mathrm{Pb}$ and $\mathrm{Nd}$ isotopes of igneous and orthogneissic rocks demonstrate that the crustal evolution of the AC involved an important addition of juvenile material during the Archean and Proterozoic, as well as a reworking of the older continental crust. In this way, part of the MIP and RSIP and the whole of the VTP and RNJP seem to have evolved from the addition of juvenile mantle-derived magmas, while the SP and part of the RSIP and MIP might be associated with the recycling of the older continental crust. So, we can estimate that about $30 \%$ of the continental crust of the AC was derived from the mantle during the Archean and about $70 \%$ during the Proterozoic.

- The available isotopic data support tectonic hypothesis, based on concepts of continuous crustal accretion during the Archean, Paleo and Mesoproterozoic times, like those proposed by Cordani et al. (1979), Tassinari (1981) and modified by Cordani and Brito Neves (1982), Teixeira et al. (1989), Tassinari et al. (1996) and Tassinari (1996). However, the synthesis concerning the tectonic setting of AC, which proposes that Precambrian tectonics is characterized by a platform reactivation process and by ensialic orogenies, with sea-floor spreading and subduction being relatively minor in the orogenic processes, still attracts some authors (Amaral 1974, Hasui et al. 1984, Costa and Hasui, 1992 and 1997).

- The division of the AC in geochronological provinces suggests that the Archean protocraton was formerly made of independent microcontinents (the Carajás-Iricoumé, Roraima, Imataca Blocks, and the West Congo craton in Africa), which were amalgamated by Paleoproterozoic orogenic belts, between 2.2 and $1.95 \mathrm{Ga}$ (MIP).

- The VTP, RNJP and part of the RSIP represent a vast area of juvenile continental crust. They were accreted to the MIP and CAP between 1.95 and $1.45 \mathrm{Ga}$ by successive magmatic arcs, probably produced by subduction of oceanic lithosphere at the beginning of the collision between a continental mass, composed at that time of the CAP and MIP against another continental mass which is now probably part of the RSIP, SP and the Laurentia (Sadowski and Bettencourt, 1995; Tassinari et al., 1996).

- Between 1.4 and 1.0 Ga, as reported by Sadowski and Bettencourt (1996), the orogenic evolution of part of the RSIP and SP took place in ensialic environments, due to continental collisions between the Amazonian Craton and Laurentia.

- Major mantle-crust differentiation events in the AC took place at 3.1-2.8 Ga (CAP); 2.8-2.5 Ga (CAP); 2.2-2.0 Ga (MIP); 2.0-1.9 Ga (VTP and RNJP); $1.9-1.7 \mathrm{Ga}$ and 1.6-1.5 Ga (RSIP) (Table 7, Figure 2). These episodes, together with the 2.0 to $0.9 \mathrm{Ga}$ anorogenic magmatic activities related to rifting and continental 
Table 7 Summary of regional geological events in the Amazoniam Craton.

\begin{tabular}{|c|c|c|c|}
\hline $\begin{array}{l}\text { Major episodes of } \\
\text { crust } \\
\text { formation }\end{array}$ & $\begin{array}{l}\text { Main events of } \\
\text { accretion of } \\
\text { juvenile crust }\end{array}$ & $\begin{array}{c}\text { Divergent } \\
\text { tectonism within } \\
\text { plate magmatism }\end{array}$ & $\begin{array}{l}\text { Sedimentary and } \\
\text { associated mag- } \\
\text { matism in conti- } \\
\text { nental rift systems }\end{array}$ \\
\hline $\begin{array}{c}1.28-1.1 \mathrm{Ga} \\
\mathrm{SP}\end{array}$ & & $\begin{array}{l}1.05-0.9 \mathrm{Ga} \\
\text { RSIP }\end{array}$ & $\begin{array}{l}1.1-1.0 \mathrm{Ga} \\
\text { RSIP }\end{array}$ \\
\hline $\begin{array}{l}1.5-1.3 \mathrm{Ga} \\
\text { RSIP }\end{array}$ & $\begin{array}{l}1.5-1.4 \mathrm{Ga} \\
\text { RSIP }\end{array}$ & $\begin{array}{l}\text { 1.45-1.2 Ga } \\
\text { RNJP }\end{array}$ & $\begin{array}{l}\text { 1.45-1.2 Ga } \\
\text { RNJP }\end{array}$ \\
\hline $\begin{array}{l}1.8-1.55 \mathrm{Ga} \\
\text { RNJP }\end{array}$ & $\begin{array}{l}1.8-1.5 \mathrm{Ga} \\
\text { RNJP }\end{array}$ & $\begin{array}{c}1.75-1.5 \mathrm{Ga} \\
\text { VTP-RNJ }\end{array}$ & $\begin{array}{l}1.65-1.4 \mathrm{Ga} \\
\text { RNJP }\end{array}$ \\
\hline $\begin{array}{c}1.95-1.8 \mathrm{Ga} \\
\text { VTP }\end{array}$ & $\begin{array}{c}1.95-1.8 \mathrm{Ga} \\
\text { VTP }\end{array}$ & $\begin{array}{c}1.85-1.8 \mathrm{Ga} \\
\text { CAP }\end{array}$ & $\begin{array}{l}1.90-1.6 \mathrm{Ga} \\
\text { CAP-VTP }\end{array}$ \\
\hline $\begin{array}{c}2.25-2.1 \mathrm{Ga} \\
\text { MIP }\end{array}$ & $\begin{array}{c}2.1-1.95 \mathrm{Ga} \\
2.25-2.1 \mathrm{Ga} \\
\mathrm{MIP}\end{array}$ & & $\begin{array}{c}1.95-1.8 \mathrm{Ga} \\
\text { CAP }\end{array}$ \\
\hline $\begin{array}{c}2.9-2.7 \mathrm{Ga} \\
\text { CAP }\end{array}$ & $\begin{array}{c}2.98-2.87 \mathrm{Ga} \\
\text { CAP }\end{array}$ & $\begin{array}{c}2.6-2.3 \mathrm{Ga} \\
\text { CAP }\end{array}$ & \\
\hline $\begin{array}{c}\text { 3.1-3.0 Ga } \\
\text { CAP }\end{array}$ & $\begin{array}{c}>3.0 \mathrm{Ga}(?) \\
\text { CAP }\end{array}$ & & \\
\hline
\end{tabular}

CAP - Central Amazonian Province VTP - Ventuari Tapajós Province RSIP - Rondonian-San Ignácio Province
MIP - Maroni-Itacaiúnas Province RNJP - Rio Negro-Juruena Province SP - Sunsás Province

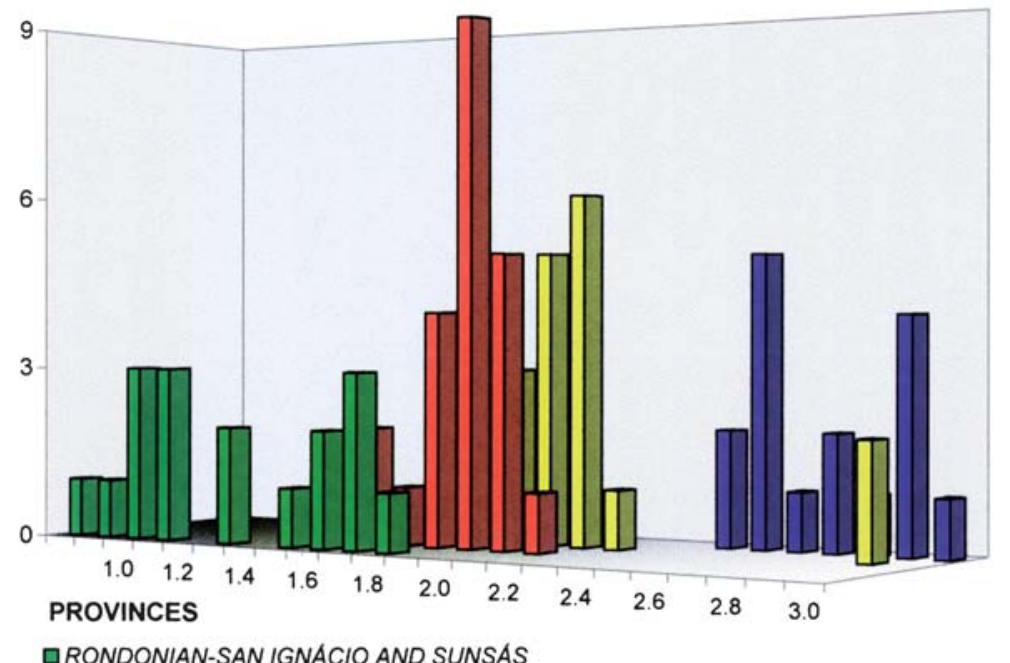

TRONDONIAN-SAN IGNACIO AND SUNSÁS

口VENTUARI-TAPAJOS AND RIO NEGRO-JURUENA

口MARONI-ITACAIUNAS

口CENTRAL AMAZONIAN

Figure 2 Histogram of the the Sm-Nd mantle-depleted model ages on granitoids and volcanic rocks from the Amazonian Craton. (After Sato and Tassinari, 1997) breakup (basic-alkaline magmatism, A-type granitoids, bimodal magmatism and deposition of platformal sediments, with decreasing ages from NE towards SW), are consistent with the hypothesis of lateral crustal growth during the Paleo- and Mesoproterozoic for the Amazonian craton.

\section{Acknowledgements}

The authors are grateful to many colleagues of the Geochronology Research Center - USP for their help in the analytical work and fruitful discussions, especially to Prof. Dr. Jorge Bettencourt. This work was supported by grants from the Brazilian Ministry of Science and Technology (PRONEX 41.96.0899.00) and the São Paulo State Foundation of Research Support (FAPESP 95/4652-2).

\section{References}

Almeida, M.E., Fraga, L.M.B., Macambira, M.J.B., 1997, New geochronological data of calc-alkaline granitoids of Roraima State, Brazil. South American Symposium on Isotope Geology. Extended Abstracts. pp 34-35.

Amaral, G., 1974, Geologia pré-cambriana da região Amazônica. Tese de Livre-Docência, Instituto de Geociências, Universidade de São Paulo. p. 212

Araújo, O.J.B., Maia, R., Jorge João, X.S., Costa, J.B.S., 1988, A megaestruturação arqueana da Folha Serra dos Carajás. VII Cong. Lat. Americ. de Geologia, Ext. Abstracts. Anais, pp.324-333.

Barrios, F.J., 1983, Caracterização geocronológica da região amazônica da Venezuela. Dissertação MSc. Instituto de Geociencias da Universidade de São Paulo, pp. 123.

Basei, M.A.S, 1987, Idade do vulcanismo ácido a intermediário na região Amazônica. (Dissert. de Msc.), Instituto de Geociências da Universidadede São Paulo, pp. 133

Bettencourt, J.S., Tosdal, R.M., Leite JR., W.B., Payolla, B.L., 1999, Mesoproterozoic rapakivi granites of the Rondônia Tin Province, southwestern border of the Amazonian craton, Brazil-I. Reconnaissance $\mathrm{U}-\mathrm{Pb}$ geochronology and regional implications. Precambrian Research, v. 95, pp. 41-67.

Cordani, U.G., Tassinari, C.C.G., Teixeira, W., Basei, M.A.S Kawashita, K., 1979, Evolução Tectônica da Amazônia com base nos dados geocronológicos. II Congresso Geológico Chileno. Arica. Chile, Actas, pp. 137-48.

Cordani, U.G., Brito Neves, B.B., 1982, The geologic evolution of Ssouth America during the Archean and Early Proterozoic. Revista Brasileira de Geociências, São Paulo, v.12, n.11-3, pp. 7888.

Costa, J.B.S., Araújo, O.J.B., Santos, A., Jorge João, X.S., Macambira, M.J.B., Lafon, J.M., 1995,. A Província Mineral de Carajás: Aspectos tectono-estructurais, estratigráficos e geocronólogicos. Bol. Mus. Para. Emílio Goeldi, v.7, pp.199-235.

Costa, J.B.S., Hasui, Y., 1997, Evolução Geológica da Amazônia. In: Costa, M.L. and Angélica, R.S. eds. Contribuiçıes à Geologia da Amazônia, Belém, SBG, pp.15-90.

Costa, J.B.S., Hasui, Y., 1992, Aspectos fundamentais do Proterozóico Médio da Amazônia Brasileira. Rev. Bras. de Geoc, v. 22 no 4, pp.87-492.

Cunha, B.C.C., Potiguar, L.A.T., Ianhez, A.C., Bezerra, P.E.L., Pitthan, J.H.L., Souza JR., J.J., Montalvão, R.M.G., Souza, A.M.S., Hildred, P.R., Tassinari, C.C.G., 1981, Levantamentos dos Recursos Naturais, v. 22, Folha SC22 Tocantins. Geologia I, NME/SG. pp. 196.

Dall'Agnol, R., Bettencourt, J.S., João, X.S., Medeiros, H., Costi, H.T., Macambira, M.J.B., 1987, Granitogenesis in Northern Brazilian Region: a Review. Rev. Bras. Geoc.,v. 17 no 4, pp. 382403.

Dall'Agnol, R., Lafon, J.M., Macambira, M.J.B., 1994, Proterozoic anorogenic magmatism in the Central Amazonian Province, Amazonian craton: geochronological, petrological and geochemical aspects. Mineral. Petrol., v. 50, pp. 113-138. 
Dall'Agnol, R., Ramo, O.T., Magalhães, M.S., Macambira, M.J.B., 1999, Petrology of the anorogenic, oxidised Jamon and Musa granites, Amazonian Craton: implications for the genesis of Proterozoic A-type granites. Lithos, v. 46, pp. 431-462.

Dall'Agnol, R., Macambira, M.J.B., 1992, Titanita-Biotita Granitos do Baixo Rio Uaupés, Província Rio Negro, Amazonas. Parte 1: Geologia, Petrografia, e Geocornologia. Rev. Bras. de Geoc., v.22, n.1, pp. 3-14.

Docegeo, 1988, Revisão litoestratigráfica da Província Mineral de Carajás. XXV Cong. Bras. de Geol. Anexo aos anais, pp. 11-56.

Egal, E., Milési, J.P., Ledru, P., Cautru, J.P., Freyssnet, P. Thiéblemont, D., Vernhet, Y., 1994, Ressources minèrales et évolution lithostructurale de la Guyane. Carte thématique minière á 1/100 000, Feuille Cayenne. Rapport BRGM, R 38019, pp.59.

Fraga, L.M, Reis, N.J., 1995, The rapakivi granite-anorthosite association of Mucajaí region - Roraima State, Brazil. Simposium on rapakivi granites and related rocks. Ext. Abst. Bull., pp.31-32

Fraga, L.M., Almeida, M.E., Macambira, M.J.B., 1997, First lead-lead zircon ages of charnockitic rocks from Central Guiana Belt (CGB) in the state of Roraima, Brazil. South American Symposium on Isotope Geology. Actas. Extended Abstracts. pp. 115-117.

Fuck, R.A., Pimentel, M.M., Machado, N., Daoud, W.K., 1993, Idade U-Pb do Granito Madeira, Pitinga (AM). 4 Cong. Bras. de Geoquimica, pp. 246-248.

Gaudette, H.E., Olszewski, Jr., W.J., 1981, Geochronology of the basement rocks, Amazonas Territory, Venezuela. I Symposium Amazonico. pp. 24-25.

Gaudette, H.E., Olszewski, W.J. and Santos, J.O.S, 1996, Geochronology of Precambrian rocks from the northern part of the Guiana shield, state of Roraima, Brazil. Journ. of South Amer. Earth Sci. V.9 n³/4 pp.183-196.

Geraldes, M.C., 1996, Estudos geoquímicos e isotópicos das mineralizaçıes auríferas e rochas associadas da região de Pontes e Lacerda, (MT). Dissertação de MSc., Instituto de Geociências da Universidade de Campinas. Pp. 104.

Geraldes, M.C., Matos, J., Ruiz, A., Fetter, A.H., Kozuch, M., Van Schmus, W.R., Tassinari, C.C.G., Teixeira, W., 1999, U/Pb constrains on Proterozoic magmatic arcs in SW Amazônia craton, Brazil. II South American Symposium on Isotope Geology. Argentina - in press.

Gibbs, A.G., Wirth, K.R., Hirata, W.K., Olszewski, W.J., 1986, Age and composition of the Grão-Pará Group volcanics, Serra dos Carajás. Rev. Bras. Geoc., v. 16, pp. 201-211.

Gibbs, A.K., 1980, Geology of Barama-Mazaruni Supergroup of Guyana. PhD Dissertation, Harvard Univ. Microfilms Intern. Ann. Aarbor MI, n.81022054, pp. 387

Gruau, G., Martin, H. Leveque, B., Capdevila, A, R., 1985, Rb/Sr and Sm/Nd geochronology of lower Proterozoic granite-greenstone terrains in French Guiana, South America. Precamb. Res. v.30 pp. 63-80.

Hasui, Y., Haraly, N.L.E., Schobbenhauss, C., 1984, Elementos geofísicos e geológicos da região amazônica: Subsídios para o modelo geotectônico. II Symposium Amazônico, Anais, pp. 129-148.

Hebeda, E.H, Boelrijk, N.A.I.M., Priem, H.N.A., Verdurmen, E.A.Th., Verschure, R.H., 1973 Excess radiogenic argon in Precambrian Avanaver dolerite in western suriname (South America) - Earth Plant. Sci. L., 20, pp. $189-200$.

Iwanuch, W., 1999, Evolução geológica com base em dados geocronológicosda porção sudeste do Estado do amazonas e do trato contíguo do norte do Estado de Mato Grosso na região do baixo e médio Rio Juruena. VI Simpósio de Geologia da amazonia, Ext. Abst. Bull., pp.467-470.

Lima, M.I.C., Santos, J.O.S, and Siga Jr., O, 1986, Os terrenos de alto grau do Craton Amazonico.Cong. Bras. de Geologia,v.2, pp.751-765.

Litherland, M. (Co-ordinador), 1986, The geology and mineral resources of the Bolivian Precambrian Shield. Overseas Mem. Br. Geol. Survey, v.9, pp. 153

Macambira, E.M.B., João, X.S.J., Lafon, J.M., Pereira, E.D., 1992, Aspectos geológicos e geocronológicos do Granito Parauari no dominio da Folha São Felix do Xingu (SB.22-y-B)-Sul do Pará. XXXVII Cong. Bras. de Geol. Anais, v.2, pp. 171-173.

Macambira, M.J.B., Lafon, J.M., 1995, Geocronologia da Província Mineral de Carajás: Síntese dos dados e novos desafios. Bol. Mus. Para. Emílio Goeldi, pp. 263-288.

Macambira, M.J.B., Lancelot, J.R., 1996, Time Constraints for the Formation of the Archean Rio Maria Crust, Southeastern Amazonian Craton, Brazil. Intern. Geology Review, v. 38, pp. 1134-1142.

Macambira, M.J.B., Lafon, J.M., Dall'Agnol, R., João, X.S.J., COSTI, H.T., 1990, Geocronologia da granitogênese da Província Amazônia Central brasileira: Uma revisão. Rev. Bras. Geoc., v. 20, pp. 258-266.
Macambira, M.J.B., Lafon, J.M., Pidgeon, R., 1998, Crescimento crustral arqueano registrado em zircies de sedimentos da região de Rio Maria, Província de Carajás, Pará. XL Cong. Bras. de Geol. Abst. bull., pp.55.

Machado, N., Lindenmayer, Z., Krogh, T.E.,Lindenmayer, D., 1991, U-Pb geochronology of archaean magmatism and basement reactivation in the Carajás area, Amazon shield, Brazil, Precamb. Res., v. 49, pp. 329-354.

Milési, J.P., Egal. EE., Ledru, P., Vernhet, Y., Thièblemont, D., Cocherie, A Tegyey, M., Martell-Jantin, B.; Lagny, P., 1995, Les mineralisations du Nord de la Guyane Française, dans leur cadre geologique. Chronique de la Recherche Minière, n. 518,pp. 5-58.

Monteiro, H., Macedo, P.M., Silva, M.D., Moraes, A.A., Marcheto, C.M.L , 1986, O greenstone belt do Alto Jaurú. XXXIV Cong. Bras. de Geol., v.2 pp. 630-646.

Montgomery, C.W. and Hurley, P.M., 1978, Total rock U-Pb and Rb-Sr systematics in Imataca Series, guyana Shield, Venezuela. Earth Plan. Science Lett., 39, pp.281-290.

Moura, C.A.V., Gorayeb, P.S. and Matsuda, N.S, 1999, Geocronologia Pb$\mathrm{Pb}$ em zircão do riolito Vila Raiol, formação iriri, Sudoeste do Pará. VI Simpósio de Geologia da amazonia, Ext. Abst. Bull., pp.475-477.

Payolla, B.L., Kozuch, M., Leite Jr., W.B., Bettencourt, J.S, Van Schmus, W.R., 1998, Novas Idades U-Pb em zircıes de gnaisses e granitóides da região de Ariquemes, Estado de Rondonia: Implicaçıes para a evolução geológica da borda sudoeste do cráton Amazônico. XL Cong. Bras. de Geologia, Anais, pp. 39.

Pidgeon, R., Macambira, M.J.B., Lafon, J.M., 1998, Datação U-Pb de estruturas primárias e secundárias de zircies de granulitos do Complexo Pium, Província de Carajás, Pará. XL Cong. Bras. de Geol., Abst. bull., pp. 56.

Pimentel, M.M. and Machado, N., 1994, Geocronologia U-Pb dos terrenos granito-greenstone de Rio Maria, Pará. XXXVIII Cong. Bras. de Geol. Ext. Abst., v.2, pp. 390-391.

Preim, H.N.A., 1973, Provisional isotope geochronological framework for some major events in the geologic column of Suriname. Geol. Mijnb. Dienst. Sur., Med. v. 22, pp. 9-16.

Preim, H.N.A., Boelrijk, N.A.I.M, Hebeda, E.H., Kuyper, R.P., De Roever, E.W.P., Verdurmen, E.A.Th, Verschure, R.H., Wilens, J.B., 1978, How old are the supposedly Archean charnockitic granulites in the guyana Shield basement of western Suriname (South America)? USGS, Open File rep. 78-701, pp. 341-343.

Rizzotto, G.L, Chemale Jr.,F., Lima, E.F., Van Schmuss, R. and Fetter, A., Dados isotópicos Sm-Nd e U-Pb das rochas da Sequência metaplutonovulcanossedimentar Nova Brail,ndia (SMNB) - RO-VI Simpósio de Geologia da amazonia, Ext. Abst. Bull., pp.490-493.

Sadowski, G.R., Bettencourt, J.S., 1996, Mesoproterozoic tectonic correlations between eastern Laurentia and the western border of the Amazonian Craton. Precambrian Res. v.76, pp. 213-227.

Santos, J.O.S., Hartmann, L.A., Gaudette, H.E., 1997, Reconnaissance U/Pb in zircon, $\mathrm{Pb} / \mathrm{Pb}$ in sulfides and review of $\mathrm{Rb} / \mathrm{Sr}$ geochronology in the Tapajós gold province, Pará/Amazonas States, Brazil. South American Symposium on Isotope Geology. Ext. Abst., pp. 280-282.

Santos, J.O.S., Silva, L.C., Faria, M.S.G., Macambira, M.J.B., 1987, Pb-Pb single crystal evaporation isotopic study on the post-tectonic, sub-alkalic, A-type Moderna granite (Mapuera intrusive suite), State of Roraima, northern Brazil. 2 Intern. Symp. Granites and assoc. mineraliz. Ext. abst., pp. 273-275.

Santos, J.O.S., Reis, N.J., Hartmann L.A., MacNaugthon, N.J., and Fletcher, I.R., 1999, Associação anortosito-charnockito-rapakivi do Calimiano do norte do Craton Amazônico, Estado de Roraima: Evidências obtidas por geocronologia U-Pb (SHRIMP) em zircão e baddeleyta VI Simpósio de Geologia da amazonia, Ext. Abst. Bull., pp.502-505.

Santos, M.V.,Tassinari, C,C,G, Souza Filho, E.E.,Teixeira, W., Ribeiro, A.C.O., Payolla, B.,Vasconi, A, 1988, Litoestratigrafia das rochas precambrianas na Bacia do medio Rio Xingu, Altamira, Para. VII Cong. Lat. Americ. de Geologia, Ext. Abstracts, pp. 363-377.

Sato, K., Tassinari, C.C.G., 1997, Principais eventos de acreção continental no Cráton Amazônico baseados em idade modelo Sm-Nd, calculada em evoluçıes de estágio único e estágio duplo. In: Costa, M.L. and Angélica, R.S., eds, Contribuiçıes à Geologia da Amazônia, Belém, SBG, pp. 91142

Schobbenhaus, C., Hoppe, A., Lork, A., Baumann, A., 1994, Idade U/Pb do magmatismo Uatumã no norte do Cráton Amazônico, Escudo da Guianas (Brasil): primeiros resultados. XXXVIII Cong. Bras. de Geol. Ext. Abst., v.2, pp. 395-397.

Tassinari, C.C.G., 1981, Evolução tectônica da Província Rio Negro-Juruena na região Amazônica. São Paulo, (Dissertação de MSc.) Instituto de Geocências, Universidade de São Paulo. 2v.,pp. 99. 
Tassinari, C.C.G., 1996, O Mapa Geocronológico do Craton Amazônico no Brasil: Revisão dos Dados Isotópicos. São Paulo, (Tese de Livre Docência) Instituto de Geociências, Universidade de São Paulo. Pp. 139.

Tassinari, C.C.G, Teixeira, W. and Siga Jr., O., 1978, Consideraçıes cronoestratigráficasda região das Chapadas do Cachimbo e Dardanelos. XXX Cong. Bras. de Geologia, v.1, pp.477-490.

Tassinari, C.C.G., Cordani, U.G., Nutman, A.P., Van Schmus, W.R., Bettencourt, J.S., Taylor, P.N., 1996, Geochronological systematics on basement rocks from the Rio Negro-Juruena Province (Amazonian Craton), and tectonic implications. Intern. Geology Review, v..38, n.2, pp. 1161175

Teixeira, W., 1978, Significação tectônica do magmatismo básico e alcalino na região Amazônica. Cong. Bras. de Geologia, v.1, pp.477-490

Teixeira, W. and Tassinari, C.C.G., 1984, Caracterização geocronológica da Província Rondoniana e suas implicaçıes geotectônicas. 2 Symposium Amazônico, Actas, pp. 87-102

Teixeira, W., Ojima, S.K. and Kawashita, K., 1984, A evolução geocronológica de rochas metamórficas e ígneas da faixa móvel MaroniItacaiúnas na Guiana Francesa. 2 Sympósium Amazônico, Actas, pp. 75 86

Teixeira, W., Tassinari, C.C.G., Cordani, U.G., Kawashita, K., 1989, A review of the geochronology of the Amazonian Craton: Tectonic Implications. Precambrian Research, v.42, pp. 213-27.

Vasquez, M.L., Klein, E.L., Quadros, M.L.E., Bahia, R.B.C, Santos, A., Ricci, P., Sachett, C.R., Silva, C.M.G, Macambira, M.J.B, 1999, Magmatismo Uatumã, na Província Tapajós-Novos dados geocronológicos. VI Simpósio de Geologia da amazonia, Ext. Abst. Bull., pp.471-474.

Vignol, L. M., 1987, Etudes geochimiques des granulites du Bresil et de la zone D'Ivree: Les elements $(\mathrm{K}, \mathrm{Rb}, \mathrm{Sr}, \mathrm{Sm}, \mathrm{Nd})$ et les isotopes radiogeniques ( $\mathrm{Sr}$ et $\mathrm{Nd})$. Diplôme d'Etudes Approfondies de Geochimie-Universite Paris VII. pp. 23.

Wirth, K.R., Gibbs, A.K., Olszewski, W.J., 1986, U-Pb ages of zircons from the Grão-Pará group and Serra dos Carajás Granite, Pará, Brazil. Rev. Bras. Geoc., v. 16, pp.195-200.
Colombo Celso Gaeta Tassinari is Professor of geochronology and isotopic geochemistry of Institut of Geoscience of University of São Paulo and head of the Geochronological Research Center of the same university. He works on the isotope geology applied to crustal evolution and metallogenesis of South America. He was joint leader of two IGCP projects: 204 "Geological Evolution of the Amazonian Craton" and 342 "Ages and Isotopes in South American Ores".

\begin{abstract}
Moacir José Buenano Macambira graduated $(M . S c)$ in geology at the University of Para-UFPa (Brazil) and concluded his Ph.D in geochronology at the University of Montpellier II (France) in 1992. He has been professor of geochronology and geochemistry of the UFPA since 1984, where he is head of the Isotope Geology Laboratory. His works are concentrated in the Amazonian craton, especially the Archean Carajás Metallogenic Province, as well as other regions of the South America, such as Bahia State (Brazil) and Argentine.
\end{abstract}
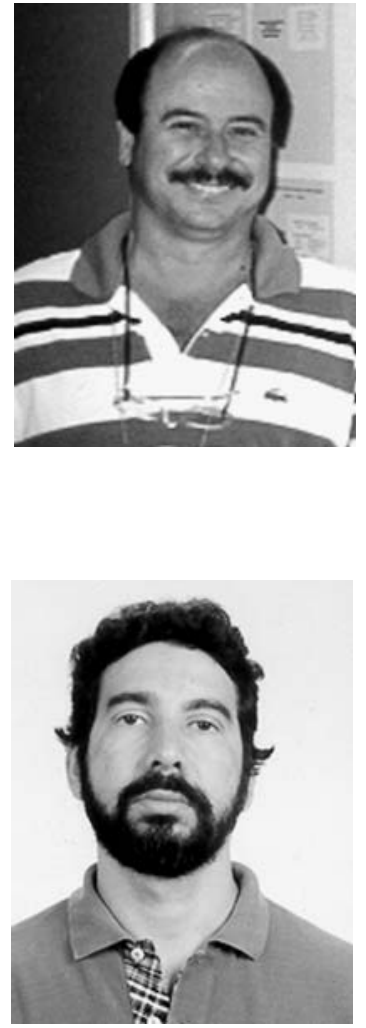

\section{Hutchison 'Young Scientist' Fund}

William Watt Hutchison, "Hutch" to his many friends around the world, was a Scots-born Canadian geologist who served Canada and the IUGS in myriad dynamic and creative ways. Most notably, he served as the IUGS Secretary General (1976-1980) at a pivotal time in its history, and as IUGS President (1984-1987). The same boundless energy, enthusiasm, skill in communications, and ability to foster teamwork that characterized his work with the IUGS also carried him to preeminent scientific administrative positions in the Canadian Government, where he served as Director General of the Geological Survey of Canada and as Assistant Deputy Minister of Earth Sciences. His distinguished career was terminated in 1987 by his untimely death at the age of 52, following a painful struggle with cancer.

One of Hutch's last wishes was to establish under IUGS auspices a memorial foundation intended to promote the professional growth of deserving, meritorious young scientists from around the world by supporting their participation in important IUGS-sponsored conferences. The first 3 beneficiaries of the Hutchinson "Young Scientist Foundation" attended the 28th International Geological Congress (IGC) in Washington, D.C., in 1989.

Currently, income earned as interest on the Hutchison fund is insufficient to sustain comparable grants every four years without seriously eroding the principal. For that reason, the IUGS made no grants from the fund for the 30th IGC, preferring instead to strengthen the fund by allowing it to earn interest for a longer period of time and by appealing for donations from the international geologic community. It is expected that grants from the fund will again support deserving young scientists to attend the 31st IGC in the year 2000. The Hutchison "Young Scientist Foundation" is a worthy cause that honors a fine, caring man and a distinguished, public-spirited scientist and administrator. The foundation also celebrates and promotes those things that gave Hutch the most professional satisfaction: geology, international scientific collaboration, and stimulating young minds.

The IUGS welcomes contributions to the Hutchison "Young Scientist Foundation." Please send donations to:

$$
\begin{aligned}
& \text { Dr. John A. Reinemund } \\
& \text { P.O. Box 890 } \\
& \text { Leesburg, VA } 20178 \text { USA } \\
& \text { Fax: +1 } 7037774463 \\
& \text { Tel: +1 } 7037771491
\end{aligned}
$$

Checks in US dollars or Visa/Mastercard (please include account number and expiration date) are preferred in order to avoid the high cost of currency conversions. Residents of the U.S.A. are reminded that charitable gifts of this nature are tax deductible. 